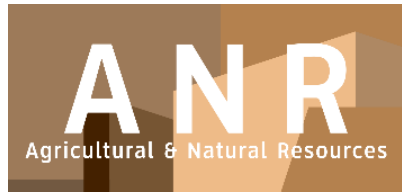

PAPER - OPEN ACCESS

\title{
Peranan Stemflow dan Throughfall Vegetasi Hutan Kota dalam Menurunkan Kandungan Unsur Kimia Hujan Asam
}

\author{
Author \\ : Bejo Slamet \\ DOI \\ Electronic ISSN \\ : 10.32734/anr.v1i1.90 \\ Print ISSN \\ : 2654-7023 \\ : 2654-7015 \\ Volume 1 Issue 2 - 2018 TALENTA Conference Series: Agricultural \& Natural Resources (ANR)
}

\section{(2) $(1)$}

This work is licensed under a Creative Commons Attribution-NoDerivatives 4.0 International License.

Published under licence by TALENTA Publisher, Universitas Sumatera Utara
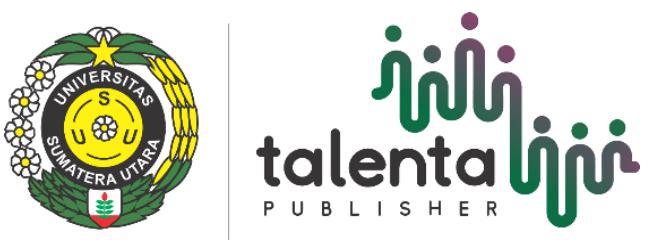


\title{
Peranan Stemflow dan Throughfall Vegetasi Hutan Kota dalam Menurunkan Kandungan Unsur Kimia Hujan Asam
}

\author{
Bejo Slamet $^{\mathrm{a}^{*}}$, Welly Hasibuan ${ }^{\mathrm{a}}$, Hidayati ${ }^{\mathrm{a}}$ \\ ${ }^{a}$ Fakultas Pertanian, Universitas Sumatera Utara, Medan, 20155, Indonesia \\ bejo@usu.ac.id
}

\begin{abstract}
Impact of acid rain on people's lives were studied but study of the vegetation role in reducing chemical elements of rainwater that reach the soil surface were limited. The purpose of this study was to analyze the role of urban forest vegetation around the Medan Industrial Zone to reducing acid rain that reached the soil surface through the mechanism of stemflow and throughfall. This research was conducted by analyzing the chemical content of stemflow and througfall water from Pterocarpus indica Will., Mangifera indica, and Gnetum gnemon plants. Parameters analyzed were water acidity (pH), electrical conductivity (EC), SO42-, NO3-, $\mathrm{NH} 4+, \mathrm{Ca} 2+, \mathrm{Mg} 2+$ and $\mathrm{Na}+$. Water analysis carried out in the Laboratory of the Environmental Agency of North Sumatra Province. The results indicate that the water that has been through the process of stemflow and throughfall consistently raises the $\mathrm{pH}$, electrical conductivity, $\mathrm{NH} 4+, \mathrm{Ca} 2+, \mathrm{Mg} 2+$ and $\mathrm{Na}+$ and reduce the content of anion SO42- and $\mathrm{NO} 3$ compared with water from open area. Stemflow and throughfall were able to reduce the content of acidic ions and increasing the content of alkali ions and reduced rain water acidity.
\end{abstract}

Kata Kunci: urban forest; acid rain; stemflow; throughfall

\section{Pendahuluan}

Keberadaan senyawa gas di atmosfer seperti $\mathrm{SOx}, \mathrm{NOx}, \mathrm{CO}_{2}, \mathrm{NO}^{3-}, \mathrm{Cl}^{-}, \mathrm{SO} 4$ akan bereaksi dengan $\mathrm{H} 2 \mathrm{O}$ dan menghasilkan berbagai asam. Keberadaan asam tersebut dapat mengakibatkan peningkatan keasaman air hujan. Sumber dari polutan tersebut yang paling utama adalah pembakaran bahan bakar fosil (BBF). Pengaruh negatif dari hujan asam dapat menimpa lingkungan abiotikmaupun abiotik yang berupa hewan, tumbuhan maupun kesehatan manusia [1].

Pengaruh hujan asam terhadap tanaman sudah cukup banyak diteliti, namun pengaruh tanaman untuk mengurangi hujan asam yang sampai di permukaan tanah di wilayah perkotaan belum banyak diteliti. Tujuan penelitian ini adalah untuk menganalisis peran vegetasi hutan kota di sekitar Kawasan Industri Medan (KIM) dalam mereduksi hujan asam melalui mekanisme stemflow dan throughfall. 


\section{Metode Penelitian}

Penelitian dilakukan pada vegetasi hutan kota yang ditanam di sekitar Kawasan Industri Medan (KIM). Penempatan penakar stemflow dan throughfall dilakukan secara purposive pada vegetasi angsana (Pterocarpusindica Will.), mangga (Mangiferaindica), danmelinjo (Gnetumgnemon) dengan masing-masing 4 titik pengukuran dan satu penakar hujan sebagai kontrol dipasang pada tempat terbuka. Penempatan penakar stemflow dan throughfall disajikan pada Gambar 1. Air yang tertampung dalam penakar kemudian dianalisis kandungan unsur kimianya. Parameter yang dianalisis adalah kemasaman air (pH), DayaHantarListrik (DHL), $\mathrm{SO}_{4}{ }^{2-}, \mathrm{NO}_{3}{ }^{-}, \mathrm{NH}_{4}{ }^{+}, \mathrm{Ca}^{2+}, \mathrm{Mg}^{2+}$, dan $\mathrm{Na}^{+}$. Analisis air dilakukan di Laboratorium Badan Lingkungan Hidup (BLH) Provinsi Sumatera Utara.

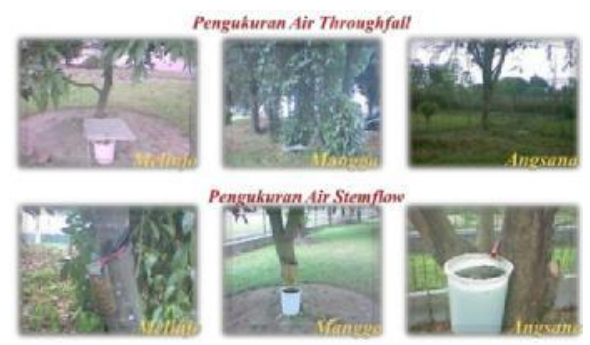

Gambar. 1. Penempatan penakar stemflow dan troughfall.

\section{Hasil dan Pembahasan}

\subsection{Perubahan Keasaman Air Hujan}

Air yang telah melalui proses stemflow dan throughfall secara konsisten mempunyai $\mathrm{pH}$ yang lebih tinggi dibandingkan dengan air hujan dari tempat terbuka. Peningkatan $\mathrm{pH}$ berarti terjadi penurunan keasaman air, sehingga air hujan yang sampai ke permukaan tanah melalui stemflow dan throughfall lebih kecil pengaruhnya dalam meningkatkan keasaman tanah.Skeffington dan Hill [5] mengemukakan bahwa rataan $\mathrm{pH}$ di bawah tegakan scot pine mampu meningkat2,85-4,30. Hasil penelitian ini menunjukkan bahwa mekanisme throughfall mampu meningkatkan $\mathrm{pH}$ air hujan berkisar 15,62\% - 27,65\% dibandingkan dengan $\mathrm{pH}$ dari air hujan. Stemflow mampu meningkatkan $\mathrm{pH}$ tanah berkisar 21,87\% - 46,21\% dibandingkan dengan $\mathrm{pH}$ dari air hujan. Rataan $\mathrm{pH}$ dari masingmasing perlakuan disajikan pada Gambar 2.

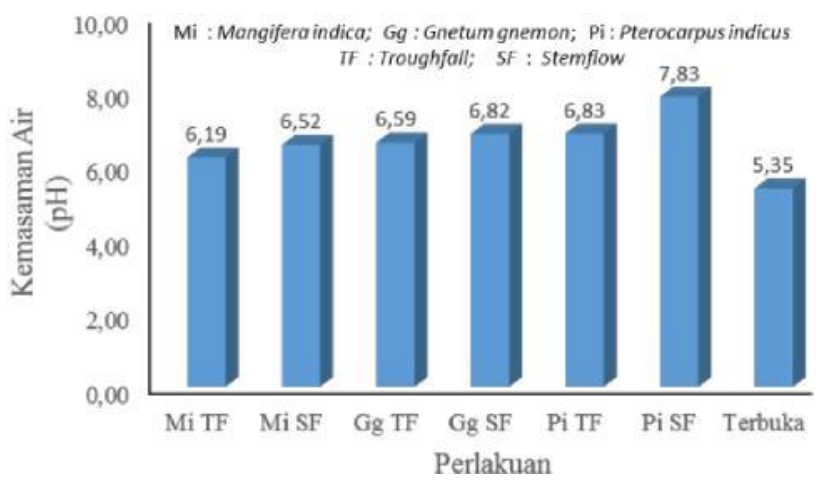

Gambar. 2. Rataan keasaman (pH) air hujan pada masing-masing perlakuan. 


\subsection{Daya Hantar Listrik (DHL)}

Daya hantar listrik merupakan besaran yang menyatakan besarnya konsentrasi ion. Peningkatan ion-ion akan meningkatkan daya hantar listrik. Menurut standar USDAbesarnya nilai DHL air hujan dari tempat terbuka mempunyai salinitas yang rendah karena nilai DHL kurang dari $250 \mu \mathrm{mhos} / \mathrm{cm}$. Sedangkan salinitas air yang telah melewati stemflow dan throughfall termasuk sedang yaitu pada kisaran $250-750 \mu$ mhos/cm kecuali air yang berasal dari stemflow tanaman Pterocarpus indicus yang termasuk dalam kategori salinitas tinggi (Gambar 3).

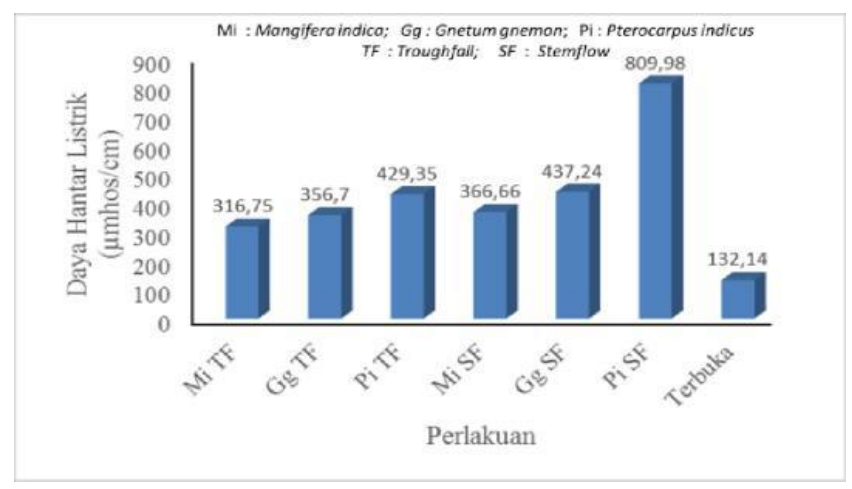

Gambar. 3. Rataan daya hantar listrik (DHL) air hujan pada masing-masing perlakuan.

\subsection{Kandungan SO42- dan NO3-}

Air hujan yang telah didistribusikan oleh tajuk tanaman melalui mekanisme stemflow dan throughfall mempunyai kandungan $\mathrm{SO}_{4}{ }^{2-}$ dan $\mathrm{NO}_{3}{ }^{-}$yang lebih rendah dibandingkan dengan air yang berasal dari tempat terbuka. Hal ini selaras dengan laporan Skeffington dan Hill [5] bahwa mekanisme throughfall telah secara dramatis mengurangi deposisi $\mathrm{SO}^{2-}$ mencapai $89 \%$. Hutan kota juga mampu menurunkan kandungan $\mathrm{SO}_{2}, \mathrm{NO}_{2}$ dan total partikel yang tersuspensi [3].

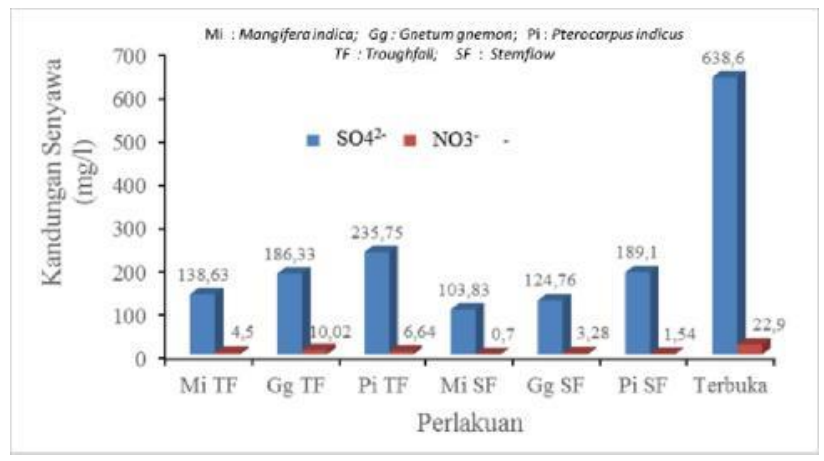

Gambar.4. Rataan kandungan $\mathrm{SO}_{4}{ }^{2-}$ dan $\mathrm{NO}_{3}{ }^{-}$air hujan pada masing-masing perlakuan.

\subsection{Kandungan $\mathrm{NH} 4+, \mathrm{Ca} 2+, \mathrm{Mg} 2+$ dan $\mathrm{Na}+$}

Stemflow dan throughfall dari vegetasi hutan kota mampu meningkatkan kandungan kation basa $\mathrm{NH}_{4+}, \mathrm{Ca}^{2+}$, $\mathrm{Mg}^{2+}$, dan $\mathrm{Na}^{+}$dibandingkan dengan hasil pengukuran air hujan dari tempat terbuka. Shen [4] mengemukakan bahwa tajuk pepohonan dilaporkan mampu meningkatkan konsentrasi kation secara signifikan yaitu mencapai 20 kali lipat 
setelah melewati proses throughfall (TF) dan stemflow (SF). Variasi kemampuan tanaman dalam meningkatkan kation dikarenakan perbedaan arsitektur tajuk, kulit batang maupun daunnya. Penelitian lain juga melaporkan bahwa Konsentrasi $\mathrm{NH}_{4+}, \mathrm{Ca}^{2+}, \mathrm{Mg}^{2+}$,dan $\mathrm{Na}^{+}$pada Stemflow dan throughfall lebih tinggi dibandingkan dengan konsentrasi yang diukur pada air hujan di tempat terbuka [2].

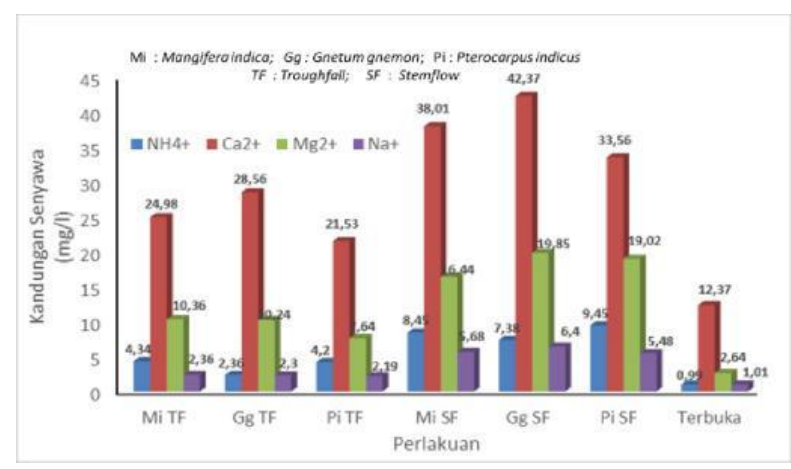

Gambar.5. Rataan kandungan $\mathrm{NH}_{4+}, \mathrm{Ca}^{2+}, \mathrm{Mg}^{2+}$, dan $\mathrm{Na}^{+}$air hujan pada masing-masing perlakuan.

\section{Kesimpulan}

Stemflow dan throughfall mampu meningkatkan pH, DHL, $\mathrm{NH}_{4}^{+}, \mathrm{Ca}^{2+}, \mathrm{Mg}^{2+}$, dan $\mathrm{Na}^{+}$serta menurunkan kandungan anion $\mathrm{SO}_{4}{ }^{2-}$ dan $\mathrm{NO}_{3-}$ dibandingkan dengan air yang tidak melalui vegetasi (pada areal terbuka). Menurunnya kandungan ion-ion asam dan meningkatnya kandungan ion-ion basa pada air yang telah melalui proses stemflow dan throughfall mampu menurunkan keasaman air hujan.

\section{Referensi}

[1] Cahyono WE. 2010. "Pengaruh Hujan Asam Pada Biotik Dan Abiotik. Berita Dirgantara." 8(10): 48-51.

[2] Germer S, Zimmermann A, Neill C, Krusche AV, Elsenbeer H. 2012."Disproportionate single-species contribution to canopy-soil nutrient flux in an Amazonian rainforest." Forest Ecology and Management. 267: 40-49. 10.1016/j.foreco.2011.11.041.

[3] Jim CY, Chen WY. 2008. "Assessing the ecosystem service of air pollutant removal by urban trees in Guangzhou (China)." J Environ Manage. 88(4): 665-676. 10.1016/j.jenvman.2007.03.035.

[4] Shen W, Ren H, Jenerette GD, Hui D, Ren H. 2013. "Atmospheric deposition and canopy exchange of anions and cations in two plantation forests under acid rain influence." Atmospheric environment. 64: 242-250.

[5] Skeffington R, Hill T. 2012. The effects of a changing pollution climate on throughfall deposition and cycling in a forested area in southern England. Science of the Total Environment. 434: 28-38. 